\title{
HAL-HAL TERKAIT TERJADINYA PENYAKIT ATAU KECELAKAAN AKIBAT KERJA PADA PERAWAT
}

\author{
Fitri Rahmadani Siregar \\ danisiregar1001@gmail.com
}

\section{Latar Belakang}

Dalam kehidupan manusia selalu mengadakan berbagai macam aktifitas. Salah satu aktivitas yang rutin dilakukan setiap orang adalah bekerja. Apapun profesi yang dipilih, bekerja bagi setiap orang selalu dilakukan dalam rangka memenuhi kebutuhan sehari-hari, mulai dari pekerjaan yang berisiko rendah hingga pekerjaan yang berisiko tinggi. Perawat adalah tenaga kesehatan yang paling besar jumlahnya dan paling lama kontak dengan pasien, sehingga sangat berisiko dengan pekerjaannya, namun banyak perawat tidak menyadari terhadap risiko yang mengancam dirinya, merupakan keselamatan dan kesehatan kerja (K3). Penyakit Akibat Kerja (PAK) dan Kecelakaan Kerja (KK) pada petugas kesehatan dan non kesehatan di Indonesia belum terekam dengan baik, data kecelakaan di Rumah Sakit belum ada laporannya.

Rumah sakit merupakan sarana pelayanan yang bergerak dibidang pelayanan jasa kesehatan yang mempunyai beragam persoalan tenaga kerja yang rumit dengan berbagai risiko terkena penyakit akibat kerja bahkan kecelakaan akibat kerja sesuai jenis pekerjaannya sehingga berkewajiban menerapkan upaya pembinaan Keselamatan dan Kesehatan Kerja Rumah Sakit (K3RS). Penyakit akibat kerja adalah penyakit yang ditimbulkan oleh atau didapat pada waktu melakukan pekerjaan. Penyakit akibat kerja atau yang lebih dikenal sebagai occupational diseases adalah penyakit yang disebabkan oleh faktor-faktor pekerjaan atau didapat pada waktu melakukan pekerjaan. Faktor Lingkungan kerja sangat berpengaruh dan berperan sebagai penyebab timbulnya Penyakit Akibat Kerja.

Perawat merupakan petugas kesehatan dengan presentasi terbesar dan memegang peranan penting dalam pemberian pelayanan kesehatan. WHO (2013) mencatat, dari 39,47 juta petugas kesehatan di seluruh dunia, 66,7\%-nya adalah perawat. Di Indonesia, perawat juga merupakan bagian terbesar dari tenaga kesehatan yang bertugas di rumah sakit yaitu sekitar 47,08\% dan paling banyak berinteraksi dengan pasien (Depkes RI, 2014). Ada sekitar dua puluh tindakan keperawatan, delegasi, dan mandat yang dilakukan dan yang mempunyai 
potensi bahaya biologis, mekanik, ergonomik, dan fisik terutama pada pekerjaan mengangkat pasien, melakukan injeksi, menjahit luka, pemasangan infus, mengambil sampel darah, dan memasang kateter.

\section{Metode}

Metode yang digunakan dalam penulisan ini adalah metode kualitatif yang dimana penulis mengumpulkan data sebanyak-banyaknya untuk dianalisis. Tulisan ini didasarkan dengan menganalisis berbagai jurnal atau karya tulis ilmiah yang berfokus pada "hal-hal terkait terjadinya penyakit atau kecelakaan akibat kerja pada perawat". Adapun tinjauan literatur yang digunakan dalam penulisan ini adalah buku teks, jurnal atau karya tulis ilmiah yang berasal dari E-book atau Google Scholar dengan syarat literatur yang digunakan terbitan 10 tahun terakhir. Penulisan ini dilakukan menggunakan metode kajian bebas terhadap pokok bahasan yang dikumpulkan dari beberapa sumber yang berkaitan dengan pokok bahasan. Pengolahan ini dilakukan dengan metode membandingkan 10 jurnal atau karya tulis ilmiah yang digunakan dan berhubungan dengan pentingnya mengetahui hal-hal terkait terjadinya penyakit atau kecelakaan akibat kerja pada perawat.

\section{Hasil}

Hasil dari pengkajian menggunakan metode penulisan kualitatif adalah menghasilkan suatu pembelajaran bagaimana pentingnya mengetahui hal-hal terkait dengan tenjadinya infeksi penyakit atau cedera akibat kecelakaan kerja pada perawat yang sering terjadi di instansi pelayanan kesehatan seperti rumah sakit melalui pengumpulan data berdasarkan buku teks, jurnal atau karya tulis ilmiah.

Hasil penelitian di beberapa negara membuktikan bahwa rumah sakit adalah salah satu tempat kerja yang berbahaya dan perawat adalah salah satu petugas kesehatan yang berisiko untuk mengalami gangguan kesehatan dan keselamatan kerja akibat dari pekerjaannya. Sebagai gambaran, biro statistik ketenagakerjaan dan Konsil Nasional Asuransi Amerika (2013) menyimpulkan pada rumah sakit di Amerika setiap 100 jam kerja terjadi 6,8 kejadian kecelakaan kerja dan penyakit akibat kerja (PAK). Angka ini menempatkan kecelakaan kerja dan PAK di rumah sakit sedikit lebih tinggi dibanding dengan kecelakaan kerja dan PAK di sektor lainnya, seperti sektor konstruksi, manufaktur dan pelayanan profesional dan bisnis lainnya. Sebanyak $48 \%$ kecelakaan kerja disebabkan karena penggunaan tenaga/otot yang berlebihan oleh perawat ketika menangani pasien, seperti mengangkat, memindahkan atau 
menjangkau pasien, dan peralatan medis lainnya. Selain itu, 54\% jenis kecelakaan yang dialami berhubungan dengan gangguan musculoskeletal, seperti sprain dan strain otot, dan hal ini menempatkan gangguan muskuloskeletal sebagai penerima klaim kompensasi terbesar dari biaya rumah sakit. Kerugian material yang harus dikeluarkan dari kecelakaan kerja dan PAK setiap tahunnya sekitar 2 Milyar US\$.

Ancaman kecelakaan kerja di tempat kerja di negara berkembang seperti Indonesia masih sangat tinggi. Hasil laporan National Safety Council tahun 1988 menunjukkan bahwa terjadinya kecelakaan kerja di rumah sakit $41 \%$ lebih besar dari pekerja industri lainnya. Kasus yang sering terjadi adalah tertusuk jarum, terkilir, sakit pinggang, tergores, luka bakar dan penyakit infeksi lainnya. Laporan lainnya di Israel angka prevalensi cedera punggung tertinggi pada perawat $(16,8 \%)$ dibandingkan pekerja industri lainnya. Di Australia, diantara 813 perawat, $87 \%$ pernah mengalami low back pain (Sholihah, 2013).

\section{Pembahasan}

Kejadian penyakit infeksi di rumah sakit dianggap sebagai suatu masalah serius karena mengancam kesehatan dan kesejahteraan pasien dan petugas kesehatan secara global (Luo, et all, 2010). Penelitian menunjukan bahwa rata-rata risiko transmisi virus melalui Blood-borne pada kecelakaan tertusuk jarum yaitu 30\% untuk virus Hepatitis B, virus Hepatitis C yaitu 3\% dan kurang lebih 0,3\% untuk virus HIC (Weston, 2008). WHO (2002) mengestimasikan bahwa sekitar 2,5\% petugas kesehatan diseluruh dunia menghadapi pajanan HIV dan sekitar 40\% menghadapi pajanan virus Hepatitis B dan Hepatitis C (Sadoh, et. all, 2006) dan 90\% dari infeksi yang dihasilkan dari pajanan tersebut berada di negara berkembang (Reda, et.all, 2010).

Rumah sakit (RS) merupakan tempat kerja yang berpotensi tinggi terhadap terjadinya kecelakaan kerja. Adanya bahan mudah terbakar, gas medis, radiasi pengion dan bahan kimia membutuhkan perhatian serius terhadap keselamatan pasien, staf dan umum (Sarastuti, 2016). Laporan National Safety Council (NSC) menunjukkan bahwa terjadinya kecelakaan di RS $41 \%$ lebih besar dari pekerja di industri lain. Kasus yang sering terjadi di antaranya tertusuk jarum atau needle stick injury (NSI), terkilir, sakit pinggang, tergores/terpotong, luka bakar, penyakit infeksi dan lain-lain (Sarastuti, 2016).

Perilaku tidak aman perawat saat bekerja tanpa menggunakan alat pelindung diri sesuai standar dapat mengakibatkan kecelakaan kerja dan menimbulkan penyakit akibat kerja. 
Cedera akibat tusukan jarum pada perawat merupakan masalah yang signifikan dalam institusi pelayanan kesehatan dewasa ini. Ketika perawat tanpa sengaja menusuk dirinya sendiri dengan jarum suntik yang sebelumnya masuk ke dalam jaringan tubuh pasien, perawat beresiko terjangkit sekurang-kurangnya 20 patogen potensial. Dua pathogen yang paling menyebabkan masalah ialah hepatitis B (HBV) dan Human Immunodeficiency Virus atau HIV. Hepatitis B adalah penyakit infeksi pada hati (hepar/liver) yang berpotensi fatal yang disebabkan oleh Virus Hepatitis B (VHB) dan merupakan salah satu penyakit yang sering ditemui dan menular. Penularannya sangat cepat, 100 kali lebih cepat dari HIV/AIDS dan dapat menyebabkan kematian.

Faktor-fakor penyebab penyakit akibat kerja dapat dibedakan sebagai berikut:

a. Faktor Fisik, yang meliputi:

1) Suara tinggi/bising yang dapat menyebabkan ketulian.

2) Temperatur/suhu tinggi yang dapat menyebabkan Hyperpireksi, Milliaria, heat Cramp, Heat Exhaustion, Heart Stroke.

3) Radiasi sinar elektromagnetik, pada mata infra merah dapat menyebabkan katarak, ultraviolet menyebabkan konjungtivitis, radioaktif/ alfa/ beta/ gama/ X menyebabkan gangguan terhadap sel tubuh manusia.

4) Tekanan udara tinggi yang dapat menyebabkan Coison Disease.

5) Getaran/vibration yang dapat menyebabkan Reynaud's Disease, Gangguan proses metabolisme, Polineurutis.

\section{b. Faktor Kimia}

1) Berasal dari bahan baku, bahan tambahan, hasil antara, hasil samping, hasil (produk), sisa produksi atau bahan buangan yang dapat berbentuk zat padat, cair, gas, uap maupun partikel. Materi ini masuk ke tubuh dapat melalui saluran pernafasan, saluran pencernaan, kulit dan mukosa.

2) Efek terhadap tubuh dapat menyebabkan iritasi, alergi, korosif, Asphyxia, keracunan sistemik, kanker, kerusakan/kelainan janin, pneumoconiosis, efek bius (narkose) dan pengaruh genetik.

c. Faktor biologi yang dapat berasal dari virus, bakteri, parasit, jamur, serangga, binatang buas, dan lain-lain.

d. Faktor Ergonomi/Fisiologi

1) Penyebabnya adalah cara kerja, posisi kerja, alat kerja, lingkungan kerja yang salah dan kontruksi salah. 
2) Efek terhadap tubuh yaitu dapat menyebabkan kelelahan fisik, nyeri otot, deformitas tulang, perubahan bentuk dan dislokasi.

\section{e. Faktor Mental/Psikologi}

1) Penyebabnya yaitu suasana kerja monoton dan tidak nyaman, hubungan kerja kurang baik, upah kerja kurang, terpencil, atau tak sesuai bakat yang mengakibatkan stress.

Kecelakaan adalah kejadian tidak terduga yang disebabkan oleh tindakan tidak aman dan kondisi tidak aman (Heinrich, 1930). Sebagian besar (85\%) kecelakaan disebabkan oleh faktor manusia dengan tindakan yang tidak aman. Tindakan tidak aman (unsafe action) adalah tindakan yang dapat membahayakan pekerja itu sendiri maupun orang lain yang dapat menyebabkan terjadinya kecelakaan yang dapat disebabkan oleh berbagai hal seperti tidak memakai APD, tidak mengikuti prosedur kerja, tidak mengikuti peraturan keselamatan kerja dan bekerja tidak hati-hati, dimana dari setiap 300 tindakan tidak aman, akan terjadi 1 (satu) kali kecelakaan yang mengakibatkan kehilangan hari kerja.

Perilaku manusia merupakan unsur yang memegang peranan penting dalam mengakibatkan kecelakaan, sehingga cara yang efektif untuk mencegah terjadinya kecelakaan kerja adalah dengan menghindari terjadinya perilaku tidak aman. Kecelakaan adalah kejadian tidak terduga yang disebabkan oleh tindakan tidak aman dan kondisi tidak aman (Heinrich, 1930). Sebagian besar (85\%) kecelakaan disebabkan oleh faktor manusia dengan tindakan yang tidak aman.

Tindakan tidak aman (unsafe action) adalah tindakan yang dapat membahayakan pekerja itu sendiri maupun orang lain yang dapat menyebabkan terjadinya kecelakaan yang dapat disebabkan oleh berbagai hal seperti tidak memakai APD, tidak mengikuti prosedur kerja, tidak mengikuti peraturan keselamatan kerja dan bekerja tidak hati-hati, dimana dari setiap 300 tindakan tidak aman, akan terjadi 1 (satu) kali kecelakaan yang mengakibatkan kehilangan hari kerja.

Pengalaman merupakan keseluruhan yang didapat seseorang dari peristiwa yang dialaminya, artinya bahwa pengalaman seseorang dapat mempengaruhi perilakunya dalam kehidupan pekerjaannya. Dengan demikian semakin lama masa kerja seseorang maka pengalaman yang diperolehnya semakin banyak yang memungkinkan perawat dapat bekerja lebih aman (Millah, 2008). Sedangkan menurut Cooper (2001) orang sering berperilaku tidak aman 
(unsafe action) karena orang tersebut belum pernah cedera saat melaksanakan pekerjaannya dengan tidak aman.

Setiap tindakan yang dilakukan oleh perawat mempunyai potensi bahaya berupa bahaya fisik, biologi, dan ergonomi. Bahaya fisik didapatkan pada pekerjaan yang menggunakan alat yang tajam, seperti memasang infus dan menjahit luka. Bahaya biologi terdapat pada tindakan invasif, merawat luka, memasang infuse, dan memberikan obat melalui rektal. Sedangkan postur janggal ketika membungkuk merupakan bahaya pekerjaan karena faktor ergonomi. Hasil penelitian ini sesuai dengan penelitian di negara berkembang lainnya oleh Ndejjo et al. (2015).

Menurut Honda dkk (2014) dalam penelitian di Thailand, terdapat hubungan yang signifikan antara sikap perawat terhadap pencegahan cidera/ kecelakaan akibat benda tajam dan terjadinya cidera akibat benda tajam. Perawat yang memiliki sikap negative terhadap pencegahan cidera benda tajam hampir dua kali cenderung terkena cidera benda tajam dibandingkan dengan yang bersikap positif. Rumah sakit dapat mengurangi jumlah kejadian tertusuk benda tajam dengan meningkatkan sikap perawat dimana sikap sangat berhubungan dengan perilaku. Penelitian ini sesuai juga dengan penelitian yang dilakukan oleh Sandewa dan Adhiwijaya (2014) bahwa sikap ada hubungan dengan kejadian kecelakaan kerja.

Menurut Hunter (1975) dalam Dhika (2011) Umur juga mempunyai pengaruh yang penting terhadap kejadian kecelakan kerja. Golongan umur tua mempunyai kecenderungan yang lebih tinngi untuk mengalami kecelakaan akibat kerja dibandingkan dengan golongan umur muda karena umur muda mempunyai reaksi dan kegesiatan yang lebih tingggi.

Perilaku ksehatan dan keselamtan kerja perawat dalam Notoatmodjo (2010) menunjukkan bawah perilaku merupakan tindakan atau aktivitas dalam upaya mencegah terjadinya penyakit akibat kerja dan kecelakan akibat kerjadan kecelakan akibat kerja. Perilaku manusia manuasia mencakup aktivitas baik yang dapat di amati maupun yang tidak dapat diamti maupun yang tidak dapat diamati oleh pihak luar sebagai sebagai hasil daris proses pembelajaran. Perilaku dibedakan menjadi dua yaitu perilaku tertutup (conver behavior) dan perilaku terbuka (overt behavior). Perilaku tetutup adalah respon seseorang terhadap stimulus dalam bentuk terselubung atau tertutup yang masih terbatas pada perhatian, persepsi, pengetahuan, kesadaran, dan sikap yang terjadi pada orang menerima setimulus tersebut, dan belum dapat di amati secara jelas oleh orang lain. 
Berdasarkan Undang-undang nomor 1 tahun 1970 tentang keselamatan kerja yang bertujuan untuk memberikan perlindungan bagi karyawan dan masyarakat umum. Undang-undang ini tidak menghendaki sifat kuratif atau korektif atas kecelakaan kerja, melainkan kecelakaan kerja harus di cegahjangan sampai terjadi dan lingkungan kerja harus memenuhi syarat-syarat kesehatan. Tuntutan pengelolaan program kesehatan dan keselamatankerja di Rumah Sakit (K3RS) semakin tinggi karena pekerja, pengunjung pasien, dan masyarakat sekitar RumahSakit inginmendapatkan perlindungan dari gangguan kesehatan dan kecelakaan kerja, baik sebagai dampak proses kegiatan pemberian pelayanan maupun karena kondisi sarana dan prasarana yang ada di Rumah Sakit yang tidak memenuhi standar (Kemenkes No. $1078 / 2010)$.

\section{Penutup}

Kehidupan manusia tidak pernah terlepas dari pekerjaan, apapun jenis pekerjaan selalu dilakukan dalam rangka memenuhi kebutuhan sehari-hari, mulai dari pekerjaan berisiko rendah hingga berisiko tinggi. Disamping itu pemahaman dan penerapan keselamatan dan kesehatan kerja (K3) masih kurang di perhatikan oleh pekerja formal maupun informal. Pada hal faktor K3 sangat penting dan harus diperhatikan oleh pekerja dan hal ini menjadi tanggung jawab bersama, perlu adanya kerja sama antara rumah sakit, dan tenaga kesehatan agar terhindar dari Kecelakaan Akibat Kerja (KAK) dan Penyakit Akibat Kerja (PAK).

Keselamatan dan Kesehatan Kerja merupakan upaya perlindungan tenaga kerja dari bahaya, penyakit dan kecelakaan akibat kerja maupun lingkungan kerja. Penegakan diagnosis spesifik dan sistem pelaporan penyakit akibat kerja penting dilakukan agar dapat mengurangi dan atau bebas dari kecelakaan kerja dan penyakit akibat kerja yang pada akhirnya dapat meningkatkan efisiensi dan produktivitas kerja. 


\section{Referensi}

Ardenny .(2015). Faktor Yang Berhubungan Dengan Kecelakaan Kerja Pada Perawat Di Rumah Sakit Jiwa Tampan PekanBaru Tahun 2015. Jurnal Proteksi Kesehatan, 4(1),1-6.

Hanifa,N.,D. (2017). Hubungan Pengetahuan dengan Upaya Penerapan K3 pada Perawat. Bandung Meeting on Global Medicine \& Health (BaMGMH), 1(1).

Istih,S.,M,P.Wiyono,J.,\& Candrawati E. (2017). Hubungan Unsafe Action Dengan Kecelakaan Kerja Pada Perawat Di Rumah Sakit Panti Waluya Malang. Nursing News, 2 (2).

Maria, P I., Wiyono J., \& Candrawati. E. (2015). Kejadian Kecelakaan Kerja Perawat Berdasarkan Tindakan Tidak Aman. Jurnal Care, 3(2).

Mantiri, E. Z. R. A., Pinontoan, O. R., Mandey, S. (2020). Faktor Psikologi Dan Perilaku Dengan Penerapan Manajemen Keselamatan Dan Kesehatan Kerja Rumah Sakit. Jurnal of Public Health and Community Medicine, 1(3), 2721-9941.

Pitoyo, J., Hamarno, R., \& Sa'adah, T. E. (2017). Kepatuhan Perawat Menerapkan Pedoman Keselamatan Kerja Dan Kejadian Cedera Pada Perawat Instrumen Di Instalasi Bedah Sentral. Jurnal Pendidikan Kesehatan, 6(2), 65-70.

Putri, S., Santoso, \& Rahayu, E. P. (2018). Pelaksanaan Keselamatan Dan Kesehatan Kerja Terhadap Kejadian Kecelakaan Kerja Perawat Rumah Sakit. Jurnal Endurance, 3(2), 271277.

Salawati, L. (2015). Penyakit Akibat Kerja Dan Pencegahan. Jurnal Kedokteran Syiah Kuala, $15(2)$.

Simamora, R. H. (2017). A strengthening of role of health cadres in BTA-Positive Tuberculosis (TB) case invention through education with module development and video approaches in Medan Padang bulan Comunity Health Center, North Sumatera Indonesia. International Journal of Applied Engineering Research, 12(20), 10026-10035.

Simamora, R. H., \& Saragih, E. (2019). Penyuluhan kesehatan terhadap masyarakat: Perawatan penderita asam urat dengan media audiovisual. JPPM (Jurnal Pendidikan dan Pemberdayaan Masyarakat), 6(1), 24-31.

Suarniti, L. H. (2015). Risiko Ergonomi Penyakit Akibat Kerja Pada Perawat Gigi. Jurnal Kesehatan Gigi, 3(2). 
Tukatman., Sulistiawati,,Purwaningsih.,\& Nursalam. (2015). Analisis Keselamatan Dan Kesehatan Kerja Perawat Dalam Penanganan Pasien Di Rumah Sakit Benyamin Guluh Kabupaten Kolaka. Jurnal Ners, 10 (2),343-347. 